\begin{tabular}{|c|c|} 
Jurnal Ayurveda Medistra \\
ISSN. 2656-3142 | Volume 4 Nomor Februari 2022 | pages: 9 - 14 \\
Avalaible online at http://ojs.stikesmedistra-indonesia.ac.id/
\end{tabular}

\title{
HUBUNGAN PERSEPSI TENTANG DAMPAK PORNOGRAFI DENGAN PERILAKU MENGAKSES SITUS PORNOGRAFI PADA REMAJA
}

\author{
Hilda Meriyandah', Yulif Maulidia1, Lina Indrawati1 \\ 1Program Studi Keperawatan (S1) STIKes Medistra Indonesia, hilda.meiryandah@gmail.com, 081294789092 \\ 1Program Studi Keperawatan (S1) STIKes Medistra Indonesia, yulifmaulidia7@gmail.com, 087887938809 \\ 1Program Studi Keperawatan (S1) STIKes Medistra Indonesia, aisyah150416@gmail.com, 0816317244
}

\begin{abstract}
Abstrak
Latar belakang: Perilaku remaja mengakses situs porno menjadi suatu kasus yang cukup tinggi saat ini. Perilaku tersebut dipengaruhi oleh beberapa faktor dorongan baik dari luar maupun dari dalam diri remaja itu sendiri. Salah satu faktor dorongan dari dalam remaja sendiri yaitu persepsi remaja itu sendiri. Persepsi tentang dampak pornografi merupakan cara pandang remaja terhadap ha-hal yang terkait dari bahaya pornografi.

Tujuan: Mengetahui karakteristik remaja berdasarkan umur, usia dan pemanfaatan internet, serta mengetahui Hubungan Persepsi Tentang Dampak Pornografi Dengan Perilaku Mengakses Situs Pornografi Pada Remaja.

Metode Penelitian ini menggunakan studi Korelasional dengan pendekatan Cross-sectional bertujuan untuk menganalisis hubungan persepsi tentang dampak pornografi dengan perilaku mengakses situs pornografi pada remaja yang dipilih secara proporsional. Populasi penelitian ini adalah seluruh remaja di RW 02 Perumahan Green Garden Rorotan dengan jumlah 102 remaja. Teknik pengambilan sampel pada penelitian ini menggunakan proporsional stratified random sampling, sehingga sampel berjumlah 89 remaja .
\end{abstract}

Hasil: Data penelitian diperoleh dengan menggunakan skala Likert. Hasil penelitian dari 89 responden (100\%) menunjukan responden yang memiliki persepsi negatif mengakses situs pornografi kategori tinggi sebanyak 23 $(25,8 \%)$, responden mengakses situs pornografi kategori rendah sebanyak $2(2,2 \%)$, responden persepsi positif dengan perilaku mengakses situs porno kategori tinggi sebanyak $38(42,7 \%)$ dan responden mengakses situs porno dengan kategori rendah sebanyak $26(29,2 \%)$.

Kesimpulan: Analisis uji chi-square diperoleh nilai $\rho$-value yaitu $0,003 \leq \alpha(0,05)$ maka dapat disimpulkan terdapat hubungan yang signifikan antara persepsi tentang dampak pornografi dengan perilaku mengakses situs pornografi pada remaja.

Kata kunci: Persepsi,Dampak Pornografi, Perilaku Remaja, Situs Porno

\section{PENDAHULUAN}

Media massa merupakan sarana atau saluran informasi yang melakukan penyebaran informasi secara keseluruhan yang dapat diakses oleh setiap masyarakat. Produk media massa yang sering digunakan yaitu media internet, karena merupakan media yang sangat mudah digunakan untuk semua kalangan masyarakat. Pengguna media internet didominasi kalangan remaja, sudah dibuktikan dengan oleh survey Pew Research Center's Internet dan American Life Project pada tahun 2012 yang menunjukan bahwa remaja cenderung lebih banyak menggunakan media internet dibandingkan yang lain (Duggan \& Brenner, 2013). Sama halnya dilndonesia pengguna media internet terbanyak didominasikan oleh kalangan remaja (Kurniawan, 2018).

Media internet merupakan media yang sangat mudah dijangkau untuk mengakses situs-situs pornografi. Hasil data laporan American Demographic Negozine dalam (Kurniawan, 2018) membuktikan bahwa pengguna situs pornografi meningkat setiap detiknya 28.258 pengguna yang melihat situs pornografi dimedia internet. End Child 
Prostitution, Child Pornography And Trafficking of Children for Sexual Purposes (ECPAT) menyatakan bahwa pada tahun 2015 dan tahun 2016 Indonesia menempati peringkat ke 2 terbanyak mengakses dan mengonsumsi video pornografi.

Remaja dengan rata-rata usia $12-17$ tahun menjadi pengguna situs pornografi terbanyak melalui media internet (Fadlulloh F, 2015). Hal tersebut tentunya didukung oleh Attorney General's Final Report on Pornography,1986 (Riska, 2017) yang menunjukan bahwa remaja usia 12 - 17 tahun menjadi frekuensi terbanyak dalam mengonsumsi pornografi melalui internet, majalah dan tabloid.

Hasil survey yang dilakukan Komisi Perlindungan Anak Indonesia (KPAl) tahun 2016 terhadap 4.500 remaja yang berada di 12 kota besar menemukan bahwa hampir 97\% remaja pernah mengakses situs pornografi, begitu juga dari 2.818 remaja yang masih menduduki bangku sekolah SMP dan SMA $60 \%$ pernah mengakses situs pornografi. Pada tahun 2019 KPAI melakukan survey kembali dan didapatkan hasil bahwa 65,34\% remaja usia $10-19$ tahun pernah mengakses situs pornografi di internet.

Menurut World Health Organization (WHO) usia remaja dapat juga dibagi menjadi 3 batasan yaitu early (10-14 tahun), middle (15-17 tahun), dan late (18-19 tahun). Masa remaja diawali dengan terjadinya kematangan organ reproduksi yang memberikan banyak perubahan salah satunya minat seksual. Meningkatnya minat seksual pada remaja tersebut mendorong remaja mencari tahu informasi yang berkaitan dengan seksual melalui media internet (Maisya, 2019).

Kebiasaan remaja mengakses situs porno menjadi salah satu perilaku yang salah dalam mencari informasi mengenai seks. Hal ini dipengaruhi oleh persepsi remaja tersebut terhadap pornografi. persepsi dapat menentukan perilaku remaja untuk mengakses atau tidak mengakses situs porno (Zakdiyah, 2015). Perilaku tersebut dipengaruhi oleh persepsi remaja itu sendiri. Hal itu terjadi karena adanya perkembangan kognitif remaja yang mencapai taraf formal operational. Menurut teori Piaget dalam (Zakdiyah, 2015) taraf tersebut memungkinkan remake untuk berpikir abstak, teoritik dan kritis sehinggan kata lain, pada masa remaja cenderung untuk mengubah cara berpikir dan merasakan nilai-nilai sesuai dengan taraf perkembangan intelektualnya.

Zilma dan Bryant (1982 dalam Rachmiwati Miftahul Jannah, 2017) menyatakan seseorang yang mengekspos pornografi berulang-ulang kali, cenderung memiliki persepsi menyimpang mengenai seksualitas dan permisif terhadap seksual pranikah serta peningkatan kebutuhan tipe pornografi yang lebih berat dan adiktif. Semakin sering remaja mengakses situs pornografi maka akan semakin tidak baik dalam mempersepsikan seksual pranikah, hal ini menjadi salah satu faktor mempengaruhi pola pikir remaja.

Jakarta Utara cukup dikenal sebagai wilayah yang cukup keras karena memiliki kriminal yang terbilang cukup tinggi, 1.829 kasus pada tahun 2018 yang tercatat di Polres Metro Jakarta Utara rata-rata anak-anak ataupun remaja yang menjadi pelaku tersebut. Hal ini dapat dikatakan wilayah Jakarta Utara bukan wilayah yang kondusif untuk pertumbuhan anak-anak dan remaja (Kusai, 2019). Pada tahun 2019 Polres Metro Jakarta Utara menangani 10 kasus kenakalan berupa vandalism (tawuran, penodongan, balapak liar) dan dari 10 kasus tersebut terdapat 23 kasus tersangka, pembunuhan ada 5 kasus dan dari 5 kasus tersebut terdapat 28 tersangka, penganiayaan ada 2 kasus dan dari 2 kasus tersebut terdapat 2 tersangka, pembulian ada 2 kasus, pencurian ada 5 kasus dan dari 5 kasus tersebut terdapat 9 tersangka, penjambretan 1 kasus dan terdapat 2 orang sebagai tersangka (Polres Metro Jakarta Utara, 2020).

Hasil penelitian yang dilakukan Zakdiyah (2015) di SMAN Kalisat menunjukan 67,2\% dari 131 responden pernah mengakses situs porno dan $61 \%$ dari 131 responden memiliki persepsi positif tentang pornografi. Hasil penelitian Rachmiwati Miftahul Jannah (2017) di SMPN 01 Bantul menunjukan 90,9\% responden pernah mengakses situs pornografi dan $61,2 \%$ responden memiliki persepsi sedang yang artinya setuju terhadap seks pranikah, hal ini diduga karena seringnya seseorang tersebut mengakses pornografi.

Berdasarkan hasil survey yang dilakukan peneliti di Perumahan Green Garden, didapatkan fenomena perilaku mengakses situs pornografi melalui media internet masih terjadi di kalangan remaja. Hal ini akan menyebabkan persepsi menyimpang mengenai pornografi pada kalangan remaja. Berdasarkan masalah tersebut maka "Apakah Ada Hubungan Persepsi Tentang Dampak Pornografi Dengan Perilaku Mengakses Situs Pornografi Pada Remaja Di RW 02 Perumahan Green Garden Rorotan?"

\section{METODE PENELITIAN}

Penelitian ini menggunakan desain studi korelasional (hubungan atau asosiasi), yang bersifat studi korelasional (hubungan 
atau asosiasi), yang bersifat cross sectional karena variabel bebas dan variabel terikat diambil pada satu waktu atau tidak melihat hubungan antar variabel berdasarkan perjalanan waktu (Dharma Kusuma Kelana, 2017).

\section{Metode Pengumpulan Data}

Populasi penelitian adalah seluruh remaja RW 02 Perumahan Green Garden Rorotan dengan sampel sebesar $87 \%$ dari jumlah populasi yaitu 89 remaja. Cara pengambilan sampel menggunakan nonprobability sampling dengan teknik proporsional stratified random sampling. Metode ini dilakukan untuk menentukan responden secara proporsional berdasarkan stratanya sampai memenui sampel.

Instrument yang digunakan peneliti untuk mengatur variabel independen dan variabel dependen adalah skala Likert. Lokasi penelitian dilaksanakan di RW 02 Perumahan Green Garden Rorotan. pengambilan data dilaksanakan pada bulan Agustus 2021. Total skor yang diperoleh dari hasil skala likert kategori persepsi memiliki interpretasi, persepsi positif (lebih dari cut of point 45,08 ) dan persepsi negatif (kurang dari cut of point $45,08)$. Sedangkan total skor kategori perilaku dengan interpretasi, perilaku mengakses kategori tinggi (lebih dari cut of point 27) dan perilaku mengakses kategori rendah (kurang dari cut of point 27).

Dalam penelitian ini peneliti menggunakan metode pengumpulan data dengan angket atau kuesioner yang diisi langsung oleh responden sendiri menggunakan google form. Proses pengumpulan data ini, melalui beberapa langkah-langkah sebagai berikut: pertama melakukan uji sidang proposal penelitian.kedua mengurus surat perizinan penelitian dari STIKes Medistra Indonesia kepada pihak RW 02 Perumahan Green Garden Rorotan. Ketiga melakukan koordinasi dan mendapatkan perizinan dari RW 02 Perumahan Green Garden Rorotan. Keempat mengambil data pada responden dengan cara menentukan calon responden yang memenuhi kriteria inklusi setelah melakukan proses penentuan populasi dan sampel.kelima memberikan penjelasan kepada responden tentang kuesioner yang akan diberikan melalui voice note di grup Whatsapp, apabila bersedia berpartisipasi dalam penelitian ini maka responden mengklik ceklis pada Informed Consent dan jika tidak bersedia peneliti menghargai keputusan responden. Keenam peneliti melakukan proses pengambilan data dengan metode kuesioner dan setelah data terkumpul peneliti melakukan pengolahan dan analisis data.

Variabel yang dianalisis adalah karakteristik responden pada penelitian ini, variabel independen dan variabel dependen analisa ini dilakukan secara komputerisasi dengan menggunakan program komputer SPSS versi 22 for Windows 10.

Penelitian ini menggunakan analisa chi-square. Variabel yang dianalisis adalah adanya Hubungan Persepsi Tentang Dampak Pornografi dengan Perilaku Mengakses Situs Pornografi Pada Remaja Usia 12-17 Tahun di RT.02 RW. 08 Perumahan Green Garden Rorotan.

\section{HASIL DAN PEMBAHASAN}

Pada tabel 1 menunjukkan hasil penelitian yang dilakukan pada remaja di Perumahan Green Garden RW 02 didapatkan bahwa usia responde yang terbanyak ialah usia $16-17$ tahun sebanyak 63 responden (70.8\%). Rentang usia responden sebagian besar berada pada usia remaja 15 - 18 tahun, dimana rentang usia tersebut merupakan usia remaja pertengahan (Kemenkes RI, 2016). Pada tahap perkembangan remaja pertengahan merupakan masa dimana keingin tahuan remaja lebih tinggi dibandingkan kelompok usia yang lain. Selain itu pada masa ini remaja sedang penyesuain dan pencarian identitas diri yang akan memunculkan masalah pada remaja.

Tabel 1. Distribusi Karakteristik Responden

\begin{tabular}{lcc}
\hline Umur & $\mathbf{N}$ & $\%$ \\
\hline $12-13$ & 9 & 10.1 \\
$14-15$ & 17 & 19.1 \\
$16-17$ & 63 & 70.8 \\
\hline Jenis Kelamin & $\mathbf{N}$ & $\%$ \\
\hline Laki-laki & 46 & 51.7 \\
Perempuan & 43 & 48.3 \\
\hline
\end{tabular}

Sedangkan hasil analisis karakteristik remaja berdasarkan jenis kelamin dari 89 responden terbanyak remaja dengan jenis kelamin laki - laki sebanyak 46 responden (51.7\%). Kurniawan (2018) menyatakan bahwa remaja laki - laki mengakses situs pornografi hanya sebagai hiburan, rasa penasaran tidak ketinggalan jaman dan mengisi waktu kosong. Hal tersebut yang membuat pandangan remaja menganggap sangat wajar dalam mengakses situs pornografi.

Dalam survey yang dilakukan Yustifa (2015) didapatkan bahwa laki - laki mendominasi dalam mengakses situs 
pornografi dengan tujuan memuaskan nafsu, mengetahui model sex, sekedar iseng dan menghilangkan beban. Menurut Cooper dan Scherer (dalam Asniati, 2020) jenis kelamin laki - laki sangat menentukan pemilihan dalam penggunaan internet, ini disebabkan karena adanya perbedaan secara biologis dan psikologis antara pria dan wanita. Dapat dilihat perubahan hormonal dari faktor biologis pada pria meningkatkan hormon testosterone yang membangkitkan minat yang tinggi terhadap hal yang berkaitan dengan seksual.

Tabel 2 menampilkan hasil deskriptif persepsi remaja dan perilaku mengakses situs porno. Hasil analisis yang dilakukan pada remaja berdasarkan pemanfaatan internet dari 89 responden, didominasikan oleh remaja yang sering memanfaatkan internet dengan tingkat tinggi sebanyak 74 responden $(83.1 \%)$. Berdasarkan penelitian yang dilakukan Herdina Indrijati (2017) bahwa remaja memanfaatkan internet setiap harinya dengan tingkat yang cukup tinggi menghabiskan durasi 4 jam atau lebih. Pemanfaatan internet tidak hanya tergambar dari durasi dan frekuensi mengakses internet, tetapi juga fasilias yang dimanfaatkan oleh pengguna internet. Semakin banyak fasilitas dan semakin luasnya pemanfaatan internet tidak selalu memberik dampak positif bagi penggunanya (Novianti dan Riyanto, 2018).

Berdasarkan hasil penelitian yang dilakukan pada 89 responden dengan pemberian kuesioner persepsi remaja tentang pornografi sebanyak 18 soal berupa pernyataan, pada tabel 2 menunjukkan bahwa sebagian responden mempunyai persepsi positif yaitu sebanyak 64 responden $(71.9 \%)$ dan 25 responden $(28.1 \%)$ mempunyai persepsi negatif.

Persepsi positif responden sudah baik, hal ini menyatakan bahwa remaja menggap pornografi adalah hal yang harus dihindari dan tidak baik untuk ditonton. Para remaja pada saat ini berada ditahap remaja pertengahan (Middle adolescence) yang sudah memiliki pemahaman yang baik dan mengerti tentang dampak negatif dalam mengakses situs pornografi. Remaja yang memiliki persepsi positif tentang dampak pornografi masih melakukan perilaku mengakses situs pornografi. faktor terbesar yang mempengaruhi hal tersebut adalah masa perkembangan remaja yang memasuki tahap transisi sehingga membuat remaja lebih banyak mencari tahu informasi yang mereka inginkan, terutama informasi terkait materi seksual (Kurniawan, 2018).

Hasil penelitian yang dilakukan pada 89 responden pemberian kuesioner Perilaku Mengakses Situs Pornografi sebanyak 12 soal berupa pernyataan, pada tabel 4.5 menunjukkan bahwa dari 89 responden hampir seluruh responden pernah mengakses situs porno dengan tingkat tinggi yaitu sebanyak 61 responden $(68.5 \%)$ dan sebagian kecil responden dengan tingkat rendah dalam mengakses situs porno sebanyak 28 responden (31.5\%).

Tabel 2. Distribusi Persepsi Remaja dan Perilaku Mengakses Situs Porno

\begin{tabular}{ccc}
\hline Persepsi Remaja & N & $\%$ \\
\hline Positif & 64 & 71.9 \\
Negatif & 25 & 28.1 \\
\hline Perilaku Akses & $\mathbf{N}$ & $\%$ \\
Situs Porno & & $\%$ \\
\hline Tinggi & 61 & 68.5 \\
Rendah & 28 & 31.5 \\
\hline
\end{tabular}

Pengguna internet terbanyak untuk tujuan seksual didominasikan oleh remaja, yang menjadi salah satu perilaku tidak baik dalam mencari informasi seksual. Masa remaja memiliki rasa penasaran yang sangat tinggi terhadap hal-hal yang baru seiring dengan perkembangannya. Selain itu pada masa remaja terjadi penyesuain dan pencarian jati identitas diri, hal inilah yang dapat menimbulkan suatu masalah pada remaja.

Berdasarkan tabel 3 tentang distribusi hubungan persepsi tentang dampak pornografi dengan perilaku mengakses situs pornografi di perumahan Green Garden Rorotan RW 02. Hasil penelitian menunjukkan bahwa responden yang memiliki persepsi positif tentang dampak pornografi sebanyak 64 responden $(71.9 \%)$ dengan kategori tidak mengakses sebanyak 26 responden (29.2\%) dan pada kategori mengakses situs porno sebanyak 38 responden (42.7\%). Sedangkan dari 25 responden (28.1\%) yang memiliki persepsi negatif tentang dampak pornografi terdapat sebanyak 2 responden (2.2\%) tidak mengakses situs pornografi dan sisanya sebanyak 23 responden (25.8\%) dengan kategori mengakses situs pornografi.

Berdasarkan analisa menggunakan uji statistic Chi-Square denga SPSS pada taraf kesalahan $5 \%$ didapatkan $\rho$ sebesar 0,03 berarti $\rho<0,05$ maka $\mathrm{H}_{1}$ diterima yang artinya ada hubungan persepsi tentang dampak pornografi dengan perilaku mengakses situs pornografi di Perumahan Green Garden RW 02 Rorotan. Setelah remaja mengakses situs porno diinternet, mereka akan mempersepsikan bahwa mengakses situs porno diinternet merupakan hal yang tidak terpuji dan tidak lazim untuk ditonton sehingga remaja akan berfikir untuk tidak akan mengaksesnya kembali. Hal ini dapat dilihat 
dari hasil penelitian diatas yang menyatakan bahwa sebagian besar responden memiliki persepsi positif. Hasil inilah yang menyatakan bahwa ada hubungan persepsi tentang dampak pornografi dengan perilaku mengakses situs pornografi pada remaja.

\begin{tabular}{cccccc}
\hline Persepsi & \multicolumn{4}{c}{ Perilaku Mengakses Situs } \\
Remaja & \multicolumn{4}{c}{ Porno } \\
\cline { 2 - 4 } & \multicolumn{2}{c}{ Rendah } & \multicolumn{3}{c}{ Sedang } \\
& $\mathrm{f}$ & $\%$ & $\mathrm{f}$ & $\%$ & \\
\hline Positif & 38 & 42.7 & 26 & 29.2 & \multirow{2}{*}{0,003} \\
Negatif & 23 & 25.8 & 2 & 2.2 & \\
\hline
\end{tabular}

Persepsi positif terhadap dampak pornografi dapat diartikan bahwa responden memahami bahaya dari pornografi. hal ini diharapkan dapat menjadi pedoman bagi remaja untuk menghindari pornogrofi salah satunya situs-situs pornografi diinternet. Remaja yang memiliki persepsi positif tentang dampak pornografi dapat mengontrol diri untuk tidak berperilaku mengakses situs pornografi kembali. Namun dari hasil penelitian didapatkan bahwa remaja yang sudah memiliki perspsi positif tentang dampak pornografi masih berperilaku mengakses pornografi. Sehubungan dengan hal tersebut dapat dikatakan bahwa masih ada faktor lainnya yang dapat mempengaruhi remaja untuk berperilaku mengakses pornografi. Faktor terbesar yang mempengaruhi terhadap hal ini adalah masa perkembangan remaja yang memasuki tahap transsi membuat remaja ingin lebih banyak mencari tahu informasi yang mereka inginkan, terutama informasi seksual.

Hasil penelitian ini sejalan dengan penelitian yang dilakukan pada tahun 2015 menyatakan bahwa perilaku remaja dalam mengakses situs porno menjadi kasus yang serius pada saat ini, perilaku tersebut dapat dipengaruhi oleh beberapa faktor dorongan, baik dari dalam diri remaja tersebut maupun dari luar. Salah satu faktor dari dalam diri remaja yang mempengaruhi perilaku mengakses situs porno ialah persepsi remaja itu sendiri. Persepsi dampak pornografi remaja merupakan cara pandang remaja terhadap hal-hal terkait bahaya mengakses situs porno (Zakdiyah, 2015). Penelitian ini juga sejalan dengan penelitian yang dilakukan pada tahun 2017 yang menyatakan bahwa perubahan/inovasi teknologi dan komunikasi global membuat perkembangan persepsi seksual remaja mempengaruhi seksual bebas (Setianingsih, 2017).

Tetapi hal ini tidak sama dengan penelitian pada tahun 2021 yang menyatakan bahwa remaja yang memiliki persepsi negatif pada seksual pranikah memiliki kategori perilaku terpapar pornografi dengan tingkat rendah .Karena menurut peneliti remaja yang memiliki persepsi negative pada seksual pranikah tidak akan terpapar pornografi disebabkan remaja tersebut mengetahui dampak setelah mengakses pornografi (Suryani, 2021).

Penelitian yang dilakukan saat ini memiliki banyak keterbatasan, di antaranya peneliti kurang dapat mengontrol responden untuk mengisi kuesioner secara tepat waktu, namun dapat diantisipasi oleh peneliti dengan menghubungi responden melalui WhatsApp untuk mengingatkan mengisi kuesioner. Peneliti kesulitan mengacak sampel karena dalam populasi mempunyai 12 lapisan, tetapi peneliti dapat mengantisipasi masalah ini dengan dibantu oleh pihak ketua RT.08 Perumahan Green Garden untuk memilihkan responden secara stratifikasi di setiap lapisannya dan menghubunginya melalui grup WhatsApp. Penelitian hanya bivariat sehingga interaksi antar seluruh variabel tidak bisa digambarkan.

\section{SIMPULAN DAN SARAN}

Terdapat ada hubungan antara persepsi tentang dampak pornografi dengan perilaku mengakses situs pornografi pada remaja di Perumahan Green Garden Rorotan RW 02 dengan nilai $p$-value 0,03 yang berarti $\leq a$ $(0,05)$ hal ini menunjukkan bahwa $\mathrm{H} 1$ diterima danAda hubungan yang signifikan antara persepsi dampak pornografi dengan perilaku mengakses situs pornografi pada remaja

Peneliti sebaiknya menambah variabel yang digunakan dalam penelitian, agar dapat lebih mengetahui faktor lain yang berhubungan selain persepsi tentang dampak pornografi dengan perilaku mengakses situs pornografi. Selain itu diharapkan juga peneliti lebih memperkaya informasi terkait persepsi tentang dampak pornografi dengan perilaku mengakses situs pornografi pada remaja.

Peneliti menyarankan bagi remaja untuk lebih memahami bahaya pornografi, menghindari hal-hal yang berkaitan dengan pornografi misalnya seperti tidak mengakses konten yang berisi situs-situs porno dan ikut serta apabila ada penyuluhan/seminar terkait bahaya pornografi. Selain itu, disarankan bagi orang tua untuk memberikan control lebih bagi anakanak mereka dalam akses internet dan bagi lembaga pendidikan diharapkan untuk dapat memberikan acuan serta bimbingan dan rutin dalam mengadakan seminar/ penyuluhan tentang dampak pornografi.

Bagi peneliti selanjutnya diharapkan penelitian ini dapat memberikan masukan dan referensi baik berupa data hasil maupun teoriteori yang sudah dikemukakan. Peneliti selanjutnya dapat memperhatikan variabelvariabel lain yang memiliki pengaruh besar 
bagi seorang remaja dalam mengakses pornografi dengan cara melakukan penelitian dengan observasi langsung (wawancara)

\section{DAFTAR PUSTAKA}

[1].Asniati, 2020. Pengaruh Penggunaan Internet Terhadap Kenakalan Remaja (Siswa). BENING 4, 61-68

[2].KKBN, 2021. Kesehatan Reproduksi Remaja [WWW Document]. bkkbn.go.id.

[3].Dharma Kusuma Kelana, 2017. Metodelogi Penelitian Keperawatan. TIM, Jakarta

[4].Duggan, M., Brenner, J., 2013. The Demographics of Social Media Users2012. PewResearchCenter 114. Matematika XIII

[5].Fadlulloh F, 2015. Presentase Pornografi Di Indonesia Dan Dunia

[6].ellara, 2016. Penggunaan Internet Pada Siswa Kelas X dan XI SMA N 1 Pengasih

[7].Kemenkes RI, 2016. Metodelogi Penelitian, Modul Bahan Ajar Cetak Farmasi. Pusdik SDM Kesehat. 3.

[8].urniawan, A., 2018. Hubungan Akses Situs Porno Dengan Persepsi Remaja Tentang Pornografi. Skripsi Sekol. Tinggi IImu Kesehat. 140

[9].Ma, C.M.S., Shek, D.T.L., Lai, C.C.W., 2017. Individual differences in intentional and unintentional exposure to online pornography among Hong Kong Chinese adolescents. Int. J. Disabil. Hum. Dev. 16, 417-423. https://doi.org/10.1515/ijdhd2017-7010

[10]. Maisya, 2019. Derajat Keterpaparan Konten Pornografi Pada Siswa SMP dan SMA di DKI Jakarta dan Banten Indonesia

[11]. Mustofa, M.F., 2019. Hubungan Antara Religiusitas Diri Dengan Kecendrungan Perilaku Cybersex Pada Remaja. Sustain. 11, 1-14

[12]. Novianti, R., Riyanto, S., 2018. Tingkat Literasi Media Remaja Desa Dalam Pemanfaatan Internet. Inst. Pertan. Bogor 16, 158-171

[13]. PPolres Metro Jakarta Utara, 2020. Data Tingkat Kriminal : Tingkat Kriminalitas Yang Dilakukan Oleh Remaja Di Jakarta Utara

[14]. RRachmiwati Miftahul Jannah, N.K., 2017. Hubungan Akses Media Pornografi Dengan Persepsi Remaja Tentang Seksual Pranikah Di Smpn 01 Kasihan Bantul

[15]. Riska, 2017. Hubungan Kontrol Diri Dengan Perilaku Konsumsi Pornografi pada Remaja Laki-laki.

[16]. Setianingsih, 2017. Faktor-Faktor Yang Berhubungan Dengan Persepsi Remaja Kelas X Tentang Seksual Bebas
Di SMA Muhammadiyah Bantul Yogyakarta

[17]. Suryani, 2021. Hubungan Paparan Media Pornografi Dengan Persepsi Remaja Tentang Seksual Pranikah Di Smk Wipama Kabupaten Tangeran 1, 95-101

[18]. Yustifa, H., 2015. Hubungan Paparan Pornografi Melalui Elektronik Terhadap Perilaku Seksual Remaja 2.

[19]. Zakdiyah, L., 2015. Hubungan Persepsi Tentang Dampak Pornografi Dengan Perilaku Mengakses Situs Porno Pada Remaja Di Sman Kalisat 12

[20]. Zevriyanti, P., 2019. Pengalaman Remaja Mengakses Konten Pornografi di SMP Perintis Depok Jawa Barat. J. IIm. Kesehat. Masy. 11, 226-231 